\title{
23
}

\section{Positive Spirituality}

\author{
Theo D. McCall
}

In the great mystic traditions of the world's religions, there is a constant call to deeper awareness and an increasing connection with something greater than oneself: the Divine. There is a call to rise into a "new sphere of existence" as Pierre Teilhard de Chardin (1965, p. 103) puts it: "Beings endowed with selfawareness become, precisely in virtue of that bending back upon themselves, immediately capable of rising into a new sphere of existence".

Yet within the Christian tradition, in particular those denominations influenced heavily by the Reformation, there has long been an emphasis on the unworthiness of the individual to stand before God. We depend utterly on God and "there is nothing that we as human beings can do to bring about our own salvation" (McCall, 2017a, p. 100). The notion that we might somehow improve ourselves is something that western Christians, in particular, have struggled with, believing that "we are helpless before God and only God's grace can release us from these shackles" (Charry, 2017a, p. 8). However, positive psychology has a great gift to bestow on religious traditions, especially Christianity. Christianity has always been concerned with promoting self-examination, so a conversation with psychology can invite "Christian theology to encourage strategies for self-improvement" (Charry, 2017a, p. 16).

Within the Judeo-Christian tradition, the notion of flourishing under God's guidance and grace is key, tied as it is to the calling of humanity

T. D. McCall ( $\otimes)$

St Peter's College, Adelaide, SA, Australia

e-mail: TMccall@stpeters.sa.edu.au 
to the "missional purposes of God" (Harris, 2017, p. 66). Human beings are called to become "healthy and productive members of society" (Charry, 2017b, p. 37). Flourishing and self-improvement is at the heart of education and finds particular focus in positive education. Self-examination, or what Rowan Williams (2016) terms "self-awareness", is also an integral part of the Christian tradition, including its long-standing engagement with, and development of, formal education. Placing the two in dialogue in the context of spirituality in education is a significant and important step.

Contemporary educational philosophy within secular government educational departments rarely, if ever, addresses the notion of a spiritual life being a part of the educational institutions for which they are responsible. Religious schools, on the other hand, usually have a belief in the importance of prayer and spirituality at the foundation of their educational aims. There is a clear disconnection between the two systems in this respect. Positive education potentially provides a bridge, bringing a focus on a broad notion of spirituality to otherwise secular government/public systems, and scientifically validated approaches to potentially narrowly focussed religious schools.

The challenges are quite different across the two systems. For the secular government system, the challenge is to provide an approach to spirituality which is both accessible to all students and their families, regardless of their religious background (including those from agnostic or atheist backgrounds), as well as being acceptable to the governing bodies. In one sense, though, there is less work for secular institutions to undertake. Mindfulness and non-religiously specific meditation programs are seen as being broadly accessible and acceptable. Even yoga is seen as acceptable within the secular system, despite its deeply religious foundation, possibly because it is usually presented as a form of physical activity, somewhat removed from its religious foundation.

For religious educational systems, the challenge is greater on the surface but perhaps easier at a deeper level. The approach of positive education and its connection with a broad spirituality needs to be seen to fit within the existing faith framework. In Christian schools, the legacy of Augustine, Anselm, Luther, and Calvin, with their development of the doctrine of sin and the need for God's saving grace, cannot be underestimated. The belief in being saved by grace alone (Luther's interpretation of St Paul's letter to the Romans) "has become a non-negotiable statement of faith, certainly for churches in the Protestant tradition" (McCall, 2017a, p. 100). Nevertheless, this focus on sin and the need for God's redemption is balanced by the call to take steps to live a life of holiness (a spiritual life) and a passionate desire among Christians to act within the world for its betterment; many 
of the concepts studied through positive psychology appear throughout the scriptures, providing direct points of connection.

Bridging these two systems, this chapter considers positive spirituality, which involves acknowledging the personal spiritual growth that can occur through the use of some techniques from positive psychology. This chapter will focus on what positive spirituality might look like by looking at the notion of Life in the Spirit and the growth in joy which can come from it. In an educational context, meditative techniques such as mindfulness and stillness can be connected with the Values in Action (VIA) character strengths, the $\mathrm{ABC}$ model of self-reflection, and a focus on forgiveness, to lead a person to a heightened awareness of the spiritual life. In educational institutions, a focus on relaxation, including physical stillness, can also help bring spiritual awareness to the fore. This highlights a connection to something larger than oneself: the goal of all mystics and a noble educational objective as teachers strive to inspire a greater sense of meaning and purpose in their students.

\section{Life in the Spirit}

For religious schools, whose underlying faith traditions have a focus on a relationship with God and the subsequent self-knowledge and love of neighbour which flows from that relationship, the connection with positive spirituality is potentially quite life-giving. Using the Christian tradition as an example, the notion of a spiritual life or, as St Paul refers to it, living "by the Spirit" (Galatians 5) provides a clear link with the personal growth model emphasised by positive education (McCall, Waters, \& White, 2015, p. 34). The notion of key virtues and the underlying VIA character strengths (Peterson \& Seligman, 2004) directly connects with the Christian ideals of "self-knowledge" and "growth" (Williams, 2016). The encouragement to live "in the Spirit" (Williams, 2016, p. 76) is to focus on living out of a set of virtues, which St Paul calls the "fruit of the Spirit" (Galatians 5:22, NRSV translation). These virtues are listed as "love, joy, peace, patience, kindness, generosity, faithfulness, gentleness, and self-control". Williams (2016) connects the living out of these virtues with "ordinary kindness and practical generosity" (p. 76). 


\section{Growth}

There is a long and noble tradition of the linking of work (action and the living out of key virtues) and prayer. Laborare est orare, to work is to pray, is an established part of the monastic tradition, usually associated with the rule of St Benedict (Abbaye Saint-Pierre Solesmes, 2019). The Roman Catholic priest, Bernard Basset (1972), expresses it well when he writes, "the integrity with which one performs each task, the skill that one brings to one's craft or profession is, in a very true sense, an act of adoration to God" (p. 26). In the Benedictine tradition, the sense of work being described here is usually physical labour. However, this notion can readily be adapted to the notion of positive spirituality within education. Indeed, the very idea of giving glory to God through the achievement of excellence is a key foundational principle of Christian educational institutions. This understanding of excellence is linked to holiness or perfection. Within the Christian tradition, ultimate holiness or perfection comes through the gift of God's grace, yet, within that framework of dependency on God's grace, the Christian strives for holiness and perfection. St Paul expresses it as follows in his instructions to his young disciple Timothy: "pursue righteousness, godliness, faith, love, endurance, gentleness" (1 Timothy 6:11) and he instructs him to "train" himself in godliness (1 Timothy 4:7).

Williams (2016) puts it well, when he writes that for the Christian it is not about achieving some special kind of "goodness" or competing with one another to achieve a "level" of being good. Rather it is "about enlarging the world, and about being involved in the world" (Williams, 2016, p. 52). The notion of holiness which Williams explores is one which involves action in the world: the living out of the virtues. He notes that one of the criteria within the Roman Catholic Church for pronouncing people saints is that "they produce joy around them" (p. 51). Williams writes beautifully in this context about Archbishop Desmond Tutu. Williams suggests that there are two types of egotists in the world: those who leave room only for themselves, such is the size and shape of their ego, and those who "are so in love with themselves that they make it possible for everybody else to be in love with themselves" (p. 51). He asserts that Tutu is the latter: a person who has sensed the joy God takes in him and has learnt to love himself as a result. Yet, that love is so expansive that it embraces all around him, so that others feel they too could one day love themselves as much as Desmond Tutu loves being Desmond Tutu.

The "growth" which Williams writes about is premised on the notion that there is always something ahead for the spiritual person. We should have 
the expectation that "we will be gently, and sometimes not so gently, urged towards that new level of life" (Williams, 2016, p. 83). The link with the concept of a "growth mindset" in positive psychology is clear. In every way, including the spiritual life, we are not fixed. Although we might settle on a method of meditation and prayer that suits us, there should nonetheless be an expectation that we will be stretched. Williams reminds us that for the very early Christians, there was a sense of being pulled towards that which is ahead of us: "straining forward to what lies ahead" (Philippians 3:13). Williams (2016) summarises it as follows:

To expect to grow, to approach our prayer and our acts of worship with the quiet assumption that at the end of the exercise there will be slightly more of me than there was at the start, this is what we're called to do in sustaining 'life in the Spirit'. (pp. 83-84)

We are being drawn into an "endless mystery", as Gregory of Nyssa refers to it. In the language of positive psychology, our spiritual life is not "fixed" or static, because there is always more to learn and discover.

\section{Joy}

The outcome of growth, Williams suggests, is "joy", which he defines as "something boundary-breaking, something uncontainable" (Williams, 2016, p. 84). This is more than a fleeting sense of euphoria or even a basic notion of everything being okay, in what he refers to as a "shoulder-shrugging way" - it is rather that sense of being "connected with something so real, that it will break every boundary or container we try to confine it in" (Williams, 2016, p. 84).

This is what the Dalai Lama refers to as happiness, which is experienced at a deeper level through our mind, "such as through love, compassion, and generosity" (Lama, Tutu, \& Abrams, 2016, p. 53). It is a much deeper sense of fulfilment, which is longer lasting than the happiness brought about through the senses. This deeper experience is "true joy" (Lama et al., 2016, p. 53). The Dalai Lama, Archbishop Desmond Tutu, and Douglas Abrams (2016) identify eight key pillars of joy:

- Perspective: There are many different angles.

- Humility: I tried to look humble and modest.

- Humour: Laughter, joking is much better.

- Acceptance: The only place where change can begin. 
- Forgiveness: Free ourselves from the past.

- Gratitude: I am fortunate to be alive.

- Compassion: Something we want to become.

- Generosity: We are filled with joy.

As we live out these pillars, we cultivate the "qualities of mind and heart" (Lama et al., 2016, p. 193) which allow us to experience greater joy. We do this by "filling our mind and heart with positive thoughts and feelings" (p. 193). Williams (2016) identifies joy, along with self-awareness, stillness, and growth, as being the "building blocks of a life of discipleship" which will assist us in staying "spiritually healthy" (p. 85).

\section{Authenticity}

The growth which leads to joy is really about being authentic. "When one is alone, one is not necessarily a better person, only more genuine" (Basset, 1972, p. 39). The search for one's authentic self, such a touchstone of the contemplative tradition, can be clearly linked with the search for one's true identity, as found, for example, in the VIA character strengths (Peterson \& Seligman, 2004). The search to discover one's authentic or true self is a key notion in both the contemplative life and positive psychology. The deeply spiritual person, who practices a life of contemplative prayer, seeks to discover true sincerity in that prayer-life, which then leads to the person being "more easily themselves" (Basset, 1972, p. 39). Precisely because the life of private prayer encourages, even demands, true sincerity and the abandonment of bashfulness, the person of prayer may become more authentically true to themselves. This is more than the abandonment of pretence or hypocrisy-it is the practice of self-discovery and self-acceptance within the context of a transcendent experience.

\section{Connections with Values in Action}

Clearly, the life in the spirit that arises from positive spirituality links with the VIA virtues and character strengths. Each person who develops and grows using the tools of positive psychology is then better equipped to be a person who produces joy around them. In an educational context, the student who is aware of his or her signature character strengths and plays to them, while also developing the lesser strengths, will be far more likely to change the landscape around them in turn. The focus on character strengths, while of necessity 
needing to be focussed on the individual student, need not be limited or selfish. In the school setting, for example, there are links to be made with religion studies, which might then draw the student to a more generous and philanthropic attitude to the world around them. For instance, McCall et al. (2015, p. 35) identified at least four ways this can occur:

1. students exploring their own character strengths and how it is they can use their character strengths to serve Jesus;

2. the use of positive verse to connect students up with the positive behaviours they can adopt, as preached in the Bible, to become wise;

3. an analysis of parables using the character strengths model; and

4. analysing the actions of Jesus towards others from a strength-based perspective.

Encouraging students to explore their own character strengths in order to "serve Jesus" (McCall et al., 2015, p. 35) need not be understood as something only Christian schools or individual Christian students can undertake. The question "why did God give me these strengths?" can be asked in a more general way: "what is my purpose to serve with the strengths I have? How can I cultivate the lower strengths so as to strive for wisdom?" (McCall et al., 2015, p. 36). This is part of the growth and the joy which Williams (2016) identifies as two key components for life in the Spirit.

Presenting Bible verses to students "that encourage positive behaviour and strengths" (McCall et al., 2015, p. 36) can encourage students to continue to work on their own strengths, with the goal of strengthening their faith and their connection to God. This method uses positive psychology as a positive lens with which to interpret Scripture (McCall, 2017b, p. 39). In a secular educational context, this approach could easily be adapted by modifying the goals and stated outcomes. Instead of a "connection to Jesus", secular educational institutions could substitute the more general idea of being connected to something greater than oneself, which is the meaning of the virtue "transcendence" as described by Peterson and Seligman (2004).

A particularly fruitful approach is the analysis of the parables using the character strengths model to bring new life to the parables in a positive education context (McCall et al., 2015). As illustrated in Table 23.1, Peterson and Seligman's (2004) over-arching virtues can be illustrated in a number of parables and used as teaching materials in class.

Another example is considering the actions of the person of Jesus from a strengths-based perspective (McCall et al., 2015), which involves looking at the actions that are portrayed in the Bible and identifying strengths in 
Table 23.1 Examples of analysing parables using character strengths

\begin{tabular}{|c|c|c|c|}
\hline Parable & $\begin{array}{l}\text { Scripture } \\
\text { reference }\end{array}$ & $\begin{array}{l}\text { Links with virtues \& } \\
\text { strengths }\end{array}$ & Lesson learned \\
\hline $\begin{array}{l}\text { Parable of the friend } \\
\text { at midnight }\end{array}$ & Luke 11:5-13 & $\begin{array}{l}\text { Courage, } \\
\text { persistence }\end{array}$ & $\begin{array}{l}\text { Sticking with } \\
\text { things until it } \\
\text { results in } \\
\text { action }\end{array}$ \\
\hline $\begin{array}{l}\text { Parable of the widow } \\
\text { and the unjust judge }\end{array}$ & Luke 18:1-8 & $\begin{array}{l}\text { Courage, } \\
\text { persistence }\end{array}$ & $\begin{array}{l}\text { Sticking with } \\
\text { things until it } \\
\text { results in } \\
\text { action }\end{array}$ \\
\hline $\begin{array}{l}\text { Parable of the two } \\
\text { sons }\end{array}$ & $\begin{array}{l}\text { Matthew } \\
21: 28-31\end{array}$ & Courage, integrity & $\begin{array}{l}\text { Doing what is } \\
\text { right, not just } \\
\text { saying that } \\
\text { you will }\end{array}$ \\
\hline $\begin{array}{c}\text { Parable about } \\
\text { humility and } \\
\text { hospitality }\end{array}$ & Luke 14:7-11 & $\begin{array}{l}\text { Temperance, } \\
\text { humility }\end{array}$ & $\begin{array}{l}\text { Do not take the } \\
\text { best seat in } \\
\text { the house } \\
\text { when invited } \\
\text { to dinner }\end{array}$ \\
\hline $\begin{array}{l}\text { Parable of the } \\
\text { unforgiving servant }\end{array}$ & $\begin{array}{l}\text { Matthew } \\
18: 23-25\end{array}$ & $\begin{array}{r}\text { Temperance, } \\
\text { forgiveness }\end{array}$ & $\begin{array}{l}\text { Importance of } \\
\text { forgiving } \\
\text { others, even } \\
\text { as we have } \\
\text { been forgiven }\end{array}$ \\
\hline $\begin{array}{l}\text { Parable of the rich } \\
\text { man and Lazarus }\end{array}$ & Luke 16:19-31 & $\begin{array}{l}\text { Justice, citizenship, } \\
\text { fairness, } \\
\text { humanity, } \\
\text { kindness }\end{array}$ & $\begin{array}{l}\text { The lack of } \\
\text { compassion by } \\
\text { the rich man, } \\
\text { and the } \\
\text { fulfilment that } \\
\text { comes through } \\
\text { kindness }\end{array}$ \\
\hline
\end{tabular}

Adapted from McCall et al. (2015)

action. For instance, in a classroom activity in a year 6 class, students searched for and identified accounts of different aspects of Jesus' life (Brooke-Smith, 2014). These included accounts of his humble beginnings in a stable, what little we know of his childhood, and his miracles, parables, and passions. As a picture of him emerged, each child selected three character strengths that they believed to be Jesus' greatest. The three most popular choices were:

- Bravery: Not shrinking from threat, challenge, difficulty, or pain; acting on convictions even if unpopular.

- Leadership: Encouraging a group of which one is a member to get things done and at the same time maintain good relations within the group. 
- Hope (optimism, future-mindedness, future orientation): Expecting the best in the future and working to achieve it.

Brooke-Smith (2014) insightfully noted that "this gives pause for thought as to just how perceptive young minds can be" (p. 1).

In such an activity, the strengths and actions Jesus can be analysed from a non-faith perspective, in the sense of learning from a significant and influential historical figure. The actions of other key religious leaders can also be analysed using the same method. While William Wilberforce was a Christian, his actions in helping end the slave trade, and slavery more generally, in the British Empire's attitude can be interpreted in a way accessible to students from different or non-existent faith traditions.

\section{Links with Forgiveness}

The VIA strengths and virtues offer a number of areas that can be explored. Former Geelong Grammar Director of Student Welfare John Hendry (2019b) identified five key elements that undergird quality relationships: trust, forgiveness, integrity, hope, and compassion. In St Paul's letter to the Ephesians, in the context of "not grieving" the Spirit of God, he names two significant qualities as forgiveness and compassion or kindness (Ephesians 4:32), along with the overarching virtue of love (e.g., 1 Corinthians 13, Ephesians 5:1). In St John's Gospel (John 14:15-17, 15:9-17) and his first letter (1 John 3:11-24, 4:7-21), the virtue of love is connected inextricably with the spiritual life. From the Christian perspective, the listing of transcendence as an overarching "virtue" is a critical step in Peterson and Seligman's (2004) classification. However, the placement of forgiveness as simply one of the 24 character strengths implies (perhaps erroneously) from a Christian perspective that it is less important than Christians believe it actually is. St John links the gift of the Holy Spirit directly with forgiveness (John 20:2223). Within an educational setting, forgiveness is a key concept, particularly in pastoral care and spirituality. Hendry (2019a) goes so far as to say, "the quality of a person, a family, (a School), a community, a nation is defined by the capacity to forgive" (p. 1). Forgiveness makes a new start possible. In the words of Desmond Tutu (2007), "forgiveness is the grace by which you enable the other person to get up, and get on with dignity, to begin anew" (p. 79). Within the Christian tradition, much has been written about the importance of forgiveness, both the forgiveness which comes from Christ, as well as the forgiveness which is then given to other people, as the Lord's Prayer models 
(Matthew 6:12; Luke 11:4). Within positive education, forgiveness is critical. It is connected intimately with dignity, as Tutu maintains, but it is also crucial in changing the cycle of revenge. As the Dalai Lama and colleagues (2016) note:

If we choose to retaliate, or pay back, the cycle of revenge and harm continues endlessly, but if we choose to forgive, we break the cycle and we can heal, renewing or releasing the friendship. (p. 236)

For an educational institution, breaking the cycle of revenge and harm is foundational.

Importantly, forgiveness is not the same as approving of wrongdoing. True forgiveness, which is intimately connected in the Christian tradition with repentance, is not about ignoring destructive behaviour. As Hendry (2015) puts it, "the common good is achieved through people being upstanders, not bystanders" (p. 1). This is not simply to protect the people being harmed, but indeed to assist the wrongdoers as well, because they will also suffer in the future. As the Dalai Lama and colleagues (2016) put it, "it's out of concern for their own long-term wellbeing that we stop their wrongdoing" (p. 234). From the point of view of the hurt person, forgiveness is not about pretending that the hurt did not occur. "Forgiveness is to acknowledge that the other person did commit an offense against us - for if they did not we would have nothing to forgive" (Hendry 2019). Forgiveness is not some kind of laissez faire attitude that suggests the pain is not real or that the offence doesn't matter-rather, forgiveness depends absolutely on recognition and acknowledgement.

Critically, forgiveness is crucial for the wellbeing of those who have been hurt. The Dalai Lama, Desmond Tutu and colleagues (2016) express forgiveness as follows:

Without forgiveness, we remain tethered to the person who harmed us. We are bound to the chains of bitterness, tied together, trapped. Until we can forgive the person who harmed us, that person will hold the keys to our happiness, that person will be our jailor. When we forgive, we take back control of our own fate and our feelings. We become our own liberator. (pp. 234-235)

Sonja Lyubomirsky (2007) lists some simple techniques to help practise forgiveness. These steps can easily be incorporated into positive education or religion studies lessons, as a model of how students might incorporate forgiveness into their lives: 
- Appreciate being forgiven: remember a time when you experienced forgiveness;

- Imagine putting yourself in the offender's shoes and forgiving him or her;

- Write a letter of forgiveness;

- Practise empathy by beginning to understand another person's feelings;

- Consider charitable attributions about the offender, for example by writing the letter that you would like to receive from him or her;

- Ruminate less, as this is a barrier to forgiveness;

- Remind yourself regularly about forgiveness and make it a habit.

These can be carried out by writing in a journal or letter, imagining undertaking the steps, or role playing scenarios that practise forgiving a wrong.

The challenge for educational institutions is to rewrite behaviour management policies from the perspective of forgiveness, with a focus on the restoration of relationships and ending the cycle of retribution. It is critical, because forgiveness is "one of the most radical ways in which we are able to nourish one another's humanity" (Williams, 2016, p. 39).

\section{Cognitive Retraining and Self-Awareness}

Beyond connections with strengths and virtues, another link arises from some of the resilience training resources that focus on reframing one's thoughts (Gillham et al., 2007; Reivich et al., 2007). From the Christian perspective, the spiritual life involves a discipline of self-awareness. Williams (2016) suggests that this is particularly true in times of crisis, in which we need to examine our motive and internal drivers quite deliberately and consciously. For the Christian, this means bringing these motives and drivers to light, where they can be examined by the individual and by Christ. The believer brings the motives to the "light of Christ" that they might be healed, if necessary. The process involves stepping back, creating space around our feelings, so that the person's reactions are not immediately driven by them. Williams connects this notion of self-awareness with the ancient spiritual notions of "dispassion" or apatheia in Greek. Although apatheia is the linguistic source of the English word apathy, in the spiritual tradition it is about stepping back and observing our desires (and the desires of those around us) and how we are feeling. Several strategies focussed on cognitive retraining that appear in some positive education practices provide several connections between science and spirituality. 


\section{The ABC Model}

Arising from cognitive therapy, Albert Ellis (1957) proposed the $A B C$ technique of irrational beliefs, which focusses on identifying and purposely shifting irrational beliefs. The technique begins by identifying an Adversity that causes distress, thinking through the Beliefs that a person has about the event, and the Consequences of those beliefs. Therapeutic approaches attempt to shift how the person thinks about their beliefs, with resulting beneficial consequences. The $\mathrm{ABC}$ model depends on challenging the initial beliefs, aided by asking questions or adding tag lines to the belief (e.g., "a more accurate way of seeing this is..." and "that's not true because"), so that the challenge is valid and softens the initial emotive belief (Reivich et al., 2007). This allows alternative thoughts to emerge, which then help prevent the instinctive, often negative reaction or consequence. That is, the model encourages a person to engage in counterfactual thinking, exploring the consequences of their initial belief, and potential alternative consequences if they choose to believe something different. Reivich et al. (2007) also suggest that several common mistakes should be avoided in the moment and when reviewing one's beliefs and feelings later: denying that there is any truth to what is being said, ignoring the reality of what is actually occurring and then dealing with it, and shirking one's own responsibility in creating the situation.

In faith-based schools, there are clear links to the $\mathrm{ABC}$ model: stepping back and drawing breath so that our instinctive reaction does not dictate our subsequent behaviour. The $\mathrm{ABC}$ model is straightforward, but immensely functional, when taught well to adolescents. When a person encounters Adversity (any situation or stressor, such as a problem with one's peers or another crisis), which provokes a reaction or a Consequence (especially with strong emotional reactions such as anger, jealousy, or fear) resulting, for instance, in the person giving up or taking revenge, then the $\mathrm{ABC}$ model recommends precisely what the spiritual tradition does: taking a moment to evaluate the Beliefs (one's immediate thoughts about the situation) and to shift those beliefs (what one chooses to believe about the situation). What the $\mathrm{ABC}$ model provides to the spiritual tradition is the mechanism to bring these feelings and emotions (Beliefs) to the light of Christ in a scientifically validated way.

The ABC model provides the scientifically supported model, and the specific questions, for practising what St Ignatius termed an Examen of Consciousness, which may be defined as (Carter, 2010):

The Examen is Spirit-guided insight and a way of praying that opens our eyes to God's self-disclosure in the midst of our everyday life. It is at the same time 
a growing awareness of our own responses to this self-disclosing God. How open am I? How willing? How generous? What in me resists or blocks the gracious movement and invitation of God? God give me courage. (p. 1)

Within the Ignatian model, there are a number of steps that have been identified, which align with the $\mathrm{ABC}$ model. Bullen (2010a) comments that the Examen is often assumed to be done at the end of the day, although he prefers to do it at the very start of the day, looking back over the previous day's events and feelings. Bullen (2010a) has developed helpful steps for these examinations based on the Ignatian tradition (see Appendix A).

Within the field of education and the demands placed upon everyone in it, taking the time to take a step back and examine oneself is more important than ever. Although the Ignatian Examen and the ABC model come from quite different traditions, they both provide ways to develop self-awareness. Across both eastern and western religious traditions, numerous practices focus on cultivating self-awareness, which potentially makes it accessible within multi-faith societies, including different educational systems. Self-awareness is also considered as a core social and emotional competency (e.g., CASEL, 2018).

Although he writes as a Christian, Williams' (2016) work on awareness is also transferable across the different educational settings. He writes of the Spirit "peeling off the layers of illusion and defensiveness, so that we see things as they really are" (Williams, 2016, p. 55). In the Christian tradition, what Williams calls "holy people" help us to see the world in a different way, to notice depths and dimensions that we might otherwise miss. This same notion of spiritual people (from all and non-existent faith traditions) leading us to new insights can be used to lead students in secular educational institutions to fresh ways of viewing themselves and the world. Williams (2016, p. 55) suggests that the path to "holiness", which in a non-religious context can equally validly be expressed as the path to "wholeness", begins with two simple (though difficult) steps:

- Looking: looking at Jesus, looking at what God is like, looking at the gospel, and all that that means; and,

- Exploring: exploring where human beings are, what their needs are, what they are calling us to do, how we may help make them more human.

Within a multi-faith educational context, Jesus can be used as one example alongside other great teachers, such as the Buddha, Mohammed, and others. Educationally, taking care to avoid evangelism in secular schools and being cautious not to overstep educational boundaries within faith-based schools, 
using examples of great leaders to look at and understand pathways to wholeness can be powerful.

\section{Teflon and the Need for Approval}

Writing within the Jesuit tradition, the influential spiritual director and writer Anthony De Mello (1990) suggests that "spirituality means waking up" (p. 5). He suggests that most people never do; "they never understand the loveliness and the beauty of this thing that we call human existence" (p. 5) because they are trapped, not really wanting to wake or be "cured" but rather simply to be given "relief". He contends that there is the need for us to wake up from the "drugged" state (p. 134) that we have been in since we were young-one that centres around a need for approval of others as the measure of success in life. He argues that we are attached to specific ideas of success, which have been programmed into us from a very young age, and we act throughout life to achieve societal ideals. Of course, the conventions of success vary from culture to culture, but are often grounded in health and wealth. Yet, he writes, he has met very happy people who have been dying of cancer, and very secure people who have practically no money.

De Mellow contends that the approval of others, physical health, financial wealth, and material possessions, are illusive. He suggests that what we need is an awakening, to break free of the programming and into "reality". His technique for doing so is first to become aware of the programming and then to notice (pay attention to) the whole reality, not just the attachments (such as the need for success or approval). This paying attention is also connected with his notion of love, which he sees as sensitivity and consciousness: sensitivity "to the whole of life, to all persons; a loving heart doesn't harden itself to any person or thing" (De Mello, 1990, p. 140).

Again, we see some degree of connection with resilience training skills developed within positive education. Reivich et al. (2007) suggested Velcro and Teflon as a metaphor for the "confirmation bias", suggesting that we have a "tendency for evidence that confirms our initial beliefs to stick to us like Velcro while evidence that contradicts our initial beliefs slides off us like Teflon" (p. 50). The metaphor aims to help students (and staff) recognise that others' negativity does not need to stick to the individual, doing what De Mello advocates - breaking free of the need for success or approval that we've been programmed with as young children.

For instance, a student might believe that he gave a terrible presentation, and everyone else's was much better. He believes that everyone was laughing 
at him, resulting in a desire to cry and run away from the class. To overcome this, Reivich and colleagues (2007, p. 52) outlined a number of simple techniques to overcome the tendency for our initial beliefs (normally negative ones) to stick to us like Velcro and more positive evidence (which contradicts those initial beliefs) to slide off like Teflon. These techniques include:

- Gain perspective by asking what a best friend or parent would say (about the presentation);

- Ask yourself neutral questions that look at the event from a different perspective;

- Pretend to be a detective by looking for evidence that contradicts the initial negative thoughts (for example by asking whether every student did in fact laugh at the presentation);

- Prove the belief false by looking for positive evidence which paints a different picture (for example, what went well?).

These simple strategies do not quite do what De Mello is advocating, namely to break out of our childhood programming, with its need for others' approval in order to be successful. Nonetheless, these techniques provide a practical way forward and an accessible starting point.

\section{Mindfulness, Meditation, Contemplative Prayer, and Stillness}

In our increasingly busy world, striving for holiness depends almost completely on stillness. Self-awareness leads us to the closely related practices of meditation and contemplative prayer, as these practices are all about "finding that freedom from the immediate noise of expectations and projections and demands" (Williams, 2016, p. 79). Within the frenetic world that we so often inhabit, the demands on staff, students, and parents are relentless. The pressure to succeed is immense, whether as an academic institution meeting government-imposed testing and required academic standards, or students in achieving university entrance scores. Positive education, as it connects with mindfulness and prayer, can speak into this space.

\section{Mindfulness and Meditation}

One of the gifts of the positive education movement has been the attention given to contemplative practices, including meditation and mindfulness. The 
beauty of many approaches to mindfulness and meditation is that they can transcend individual faith backgrounds of the students and be accessible to students of all religious and non-religious backgrounds. At this point, mindfulness, in particular, is a helpful term, precisely because it has broken through into the secular educational systems as an acceptable practice. Jon Kabat-Zinn (1994) defines mindfulness as "paying attention, on purpose, in the present moment, non-judgementally" (p. 4). Within the religious tradition, mindfulness is spoken of more commonly as stillness, which includes "stillness of body as well as of mind and heart" (Williams, 2016, p. 79). Mindfulness practice can be as simple as intentionally being present in the moment and soaking up every part of life. It can be readily practised within educational institutions, but needs to be done so intentionally.

The influence of simple, Eastern meditative traditions can be seen in some of the mindfulness practices, though they are also found in contemplative Western Christianity as well. In the contemplative Christian tradition, mindfulness is more commonly described as attentiveness or awareness. In its most basic form, it simply means "to watch, to observe what is going on within you and around you" (De Mello, 1990, p. 125). De Mello identifies observation as the key strategy to the notion of awareness and breaking out of one's self-imposed and limited concept of the world. This observation can take the shape of simply looking and noticing the reality around us, by which De Mello means literally anything: "the faces of people, the shape of the trees, a bird in flight, a pile of stones, watch the grass grow. Get in touch with things, look at them" (p. 125). This is the age-old notion of wonder. In the educational context, wonder is well known as something that young children naturally do. The challenge for educationalists when working with adolescents, in particular, is to help them rediscover the beauty of wonder. De Mello (1990) categorises this as returning to paradise, by which he means that we have to fall from a stage of innocence and "be thrown out of paradise" (p. 126). This is a reference to the loss of innocence in the story of Adam and Eve in the Garden of Eden (Genesis 2 and 3) but it is also an acknowledgement that children develop concepts and understandings, which help them navigate the world. De Mello is not suggesting a return to some kind of childish, "Garden of Eden" state, but he is arguing that we need to return to wondering, in other words taking delight in the world around us.

There are a number of practical ways that mindfulness has been developed in educational settings. One of the simplest, but very powerful methods to encourage mindfulness in young children is simply a version of what De Mello describes in observing the world around us. For example, in the Early Learning Centre at St Peter's College, Adelaide, Australia, students were given 
the simple task of noticing the different types of birds and their habitats in the expansive school grounds. The sense of wonder, excitement, and delight was palpable as the students observed the birds, kept a simple mental tally of them (with the aid of the teacher), and then enjoyed looking at the photographs afterwards.

De Mello is focussing on observation or attentiveness in the visual sense, but in the school context, gentle aural stimuli also matters. Practical applications include the use of quiet music, combined with either silence or simple meditative phrases, which can easily be used in classroom settings or chapel services. A practised leader can quietly tell a story, or simply lead the students and staff present in imagining their favourite restful place. Other techniques involve painting a picture with words of a specific place known to the leader, which is particularly beautiful.

\section{The Value of Prayer}

Dispelling some of the enduring myths within secular society about contemplative prayer and spirituality needs to be a critical area of focus for positive spirituality. One such myth is the belief that deep spirituality or prayer is solely the domain of the strictly "religious" person. Prayer, in particular, has sometimes been viewed as the domain of the spiritual person. While vague notions of spirituality are prevalent in western societies, incapsulated in the oft-repeated phrase "I'm spiritual, but not religious", prayer life is arguably less common than it was in the middle of the twentieth century. This is seen most clearly in western societies as significant declines in affiliations with religion have occurred (see for example Australian Bureau of Statistics, 2016). It is doubtful that religion-based, organised prayer (previously quite widespread through high levels of religious observance) has been replaced in most people's lives by the regular, intentional practice of spirituality or mindfulness. This only makes the practice of contemplation or mindfulness even more critical in contemporary educational institutions.

Part of the reason for the association of prayer with the strictly religious is the recent historical misunderstanding of what contemplative prayer within organised religions might look like. The picture of a prayerful person spending many hours on his or her knees in church at a "mahogany priedieu" (Basset, 1972, p. 111) springs to mind. Yet the rich history of the contemplative life paints a far more varied and nuanced picture of prayer and contemplation, into which positive education might yet breathe new life. Building on the work of the fifth-century monk John Cassian, Williams (2014) suggests that "prayer takes for granted the 'practical' life ... where you 
have been monitoring your reactions and trying to educate your emotions, and also practising justice and generosity" (p. 76). This means stepping back from our instinctive reactions, which might "splurge out in all directions" (p. 68).

St Teresa of Avila (1577) describes this kind of approach to prayer as "Active Recollection":

However quietly we speak, he is so near that he will hear us. We need no wings to go in search of him, but have only to find a place where we can be alone and look upon him present within us. (chapter 28)

This prayer is otherwise known as "The Prayer of Simple Regard" which refers to giving "full attention to the person whom we love" (Basset, 1972, p. 124). Of course, St Theresa is writing within the Christian tradition, but such attentiveness, which Basset links with physical relaxation as well as a peaceful mind, transcends religious traditions. This state of relaxed attentiveness elicits an awareness of the divine which increases as the practitioner continues to pray (Basset, 1972); however, it need not be confined to use by religious people of any persuasion - this state of relaxed focus is precisely what the non-religious specific practice of mindfulness tries to achieve.

Indeed, within religious schools, it is not uncommon to find student prayer groups. These groups often use a simple formula, beginning with some socialising, reading a passage of scripture, and then entering a time of extempore prayer. What is far less common, if not almost unknown in schools, is the kind of "Mystics Anonymous" group advocated by Hugh Kempster (2015). These groups have the potential to allow students and staff from all religious and non-religious traditions to begin to explore meditation and contemplation. As described by Kempster and Yaden (2015, p. 289), the structure can be simple:

1. A short introduction by the leader of the session that may include a poem or reading;

2. Sharing stories about religious, spiritual, or mystical experiences without comment or analysis from other participants;

3. Time for contemplative, meditative silence.

A simple Ignatian method of using Bible readings to reflect deeply on the spiritual life is known as Lectio Divina (see Appendix B). This method arose within the monastic tradition to reflect on the Bible, but as is the case with many such methods and traditions, it can quite easily be adapted to reflect on other literature. 


\section{Stillness}

Basset (1972) suggests that contemplative traditions are like food for the soul or a "fountain from which the weary traveller may drink" (Basset, 1972, p. 29). For the "religious" person, quiet prayer or contemplation might be postponed, but cannot be totally replaced by the "prayer in the midst of busyness" approach. Being physically still and enjoying some physical solitude matter (Williams, 2014). Stillness is, somewhat poetically and dramatically, as important as food or sleep. Within the monotheistic faiths of Christianity, Islam, and Judaism, this call to authenticity, is about "being still enough to hear God speaking my name" (Williams, 2016, p. 78).

Eastern meditative techniques and Western monastic traditions converge particularly in the understanding of using stillness. Stillness is about "being aware of our behaviour" in "everyday matters" (Williams, 2016, p. 80). What Williams means is that we begin to be at peace within ourselves, through the intentional practice of stillness, in the midst of our daily activities. This can be as simple as deciding not to be "utterly driven" in everything we undertake, so much so that "I cannot stop and listen" (Williams, 2016, p. 80). Stillness does not necessarily mean the complete absence of noise with the use of music or simple descriptive exercises. It can also include repetitive phrases, which help the meditator to settle down and be still. The key, both with basic descriptions of meditative places and scenes, as well as simpler repeated phrases, is that they do not break the silence. Williams (2016) describes the use of simple phrases as follows:

Like waves on the beach in a calm day; just the beat of a heart; small words, small phrases that keep us steady and hold us when everything else is pushing us around. (p. 80)

Williams describes this as a way of anchoring ourselves where we are. For Christians, the simple meditative words have often taken the form of the "Prayer of Jesus" as it developed in the Easter Tradition: "Lord Jesus, Christ, Son of the living God, have mercy on me, a sinner". The monk John Cassian suggests an even shorter formula: "O God make speed to save me" (Williams, 2014, p. 79). Other approaches that Williams identifies include reciting the words of hymns or psalms, a saying of Jesus from the Gospels, or the "ancient Syriac phrase quoted by St Paul: 'Maranatha, Come, Lord"' (Williams, 2016, p. 81). These phrases anchor us by drawing us back to the meditative task at hand. They can be used as focussing chants (a mantra in the Buddhist tradition) which help us set aside distractions, particularly our own distracting thoughts. 
Within the meditative tradition, stillness is seen as critical to becoming aware of the transcendent. For people of faith, the problem is not that God is absent, but rather than we are absent. In an educational setting, with staff and students from diverse backgrounds, the issue might be rephrased as follows: the issue is not that transcendent experiences are impossible, but rather that we are absent; we are not open to the possibility or still enough to allow it to take place. Williams (2016) puts the following as a question from God:

So, when are you actually going to arrive? When are you going to sit and listen, to stop roaming about, and be present? (p. 81)

This question could just as easily be a question from "the Universe" or from a general notion of "Transcendence". To express it another way, life is happening right now. When are we going to wake up, as De Mello (1990) puts it, and start paying attention? Stillness provides a way of waking up. It connects us with the present moment. It allows us to "connect with the moment of creation, the eternal reality of God speaking, God giving, God calling us into life" (Williams, 2016, p. 82). Williams is not referring to a fixed moment in time, when writing about creation here, but rather the notion of God continually shaping us and helping us to grow.

As has been previously noted, the "great advantage of this type of contemplation is that it is open to students of all religious traditions and none" (McCall et al., 2012, p. 20). Non-religious educational institutions can easily adapt De Mello and Williams' concepts with a simple change of language. The simple phrases and prayers that Williams refers to, for example, need not be from the Christian tradition per se. Other meditative phrases can be substituted, particularly if there are legislative requirements on inclusion that need to be met.

\section{Muscular Relaxation for Mindfulness and Prayer}

Within the Western Christian tradition, the need for "muscular relaxation" (Basset, 1972, p. 100), in achieving a state of mindfulness or prayer, is being rediscovered. Earlier spiritual teachers were well aware of the need for a state of physical relaxation, in order that meaningful prayer might follow. Ignatius of Loyola was well aware of the need for a relaxed state to enable deep prayer. He advised his followers to adopt a variety of physical positions, including being stretched out on the ground in a comfortable position (Ignatius, trans. Puhl, 1951, p. 36). Yet in the Western Christian tradition at least, this is a comparatively new rediscovery. Indeed, the long tradition of kneeling for 
prayer was almost designed to have the opposite effect: to produce a state of discomfort, with the thought that this would help focus the mind of the penitent sinner on God. From an evolutionary perspective, such discomfort, particularly when it involves the tightening of the muscles, may help focus the mind, but, as Basset points out, we tighten our muscles "only when we want our body to react to a situation, to run, sit, stand, avoid a danger, side-step an accident" (Basset, 1972, pp. 100-101). This is hardly a helpful starting point for mindfulness or prayer.

Attention to the physical environment, then, is not simply a question of ensuring there is helpful lighting, music, or repetitive and meditative phrases - it also needs to include the physical state of the participants. For students of all ages, this is something that needs to be modelled and taught. At a basic level, this can be as simple as ensuring that students are comfortable and not distracted (or distracting others), but not so physically relaxed that they fall asleep (unless that is the aim, as it might be with very young students, for example).

\section{Yoga}

Finally, the place of yoga in educational settings is comparatively new in Western society, but it shows much potential. In conservative Christian circles, there is some nervousness about using a technique which has its roots in another faith tradition, but in fact, throughout its history, Christianity has consistently adopted other traditions and customs to achieve its goals of union with Christ and the transformation of the world.

As a contemplative practice, yoga can be used in at least two main ways. The simplest is an effective way to relax the body and achieve a measure of inner peace. In the context of the frenetic contemporary lifestyle of most people, this is an admirable goal in itself. As Basset (1972) puts it, "the yoga exercises are effective in teaching us how to relax our bodies and many who have small use for prayer or religion take up yoga simply to acquire peace" (p. 101). In a busy school, for example, students and staff who regularly participate in a simple yoga class can achieve a level of peace which is invaluable, particularly given the other pressures of the timetable and academic demands. For example, at St Peter's College, Adelaide, yoga has been offered as a lunchtime optional activity for students (and staff) using the most basic movements, led by a staff member who was a yoga enthusiast, and as an after-school yoga class for staff only, led by an experienced yoga teacher.

The "higher" level of yoga is one that leads the practitioner on a spiritual journey to prayer and "from the self-conscious to the cosmic conscious and 
so to consciousness of the Divine" (Basset, 1972, p. 101). This is the journey an experienced teacher will begin to elicit in their participants. The link with formal prayer is clear; there is an attentiveness and alertness in the practice of yoga, which are two key components of prayer. My own tentative theory is that true prayer occurs towards the end, or indeed following, a yoga class, especially in the way yoga is typically practised in the West. Of course, it is highly individual, but the relaxation initiated in a yoga class can then permit the person to be fully attentive and self-aware, which in turn might "supply a control of the imagination, which is invaluable in prayer" (Basset, 1972, p. 105).

Such imagination in prayer can be as straightforward, but therapeutic nonetheless, as leading the person to a quiet place of stability and peace. It may also enable the participant to imagine themselves in a Gospel scene, for example, seeing themselves as part of the crowd on the shore of the Sea of Galilee, while Jesus teaches from Simon Peter's boat (Luke 5:30). The possibilities are almost endless. A Christian yoga teacher, for example, could conclude a session with a relaxing meditative scene, in which the class members visualise themselves in a beautiful scene from Jesus' life. This imaginative contemplation of a Gospel scene can pass, Basset (1972) suggests, "to the deepest forms of mystical prayer" (p. 111).

\section{Conclusion}

An awareness of transcendence, of being connected with something larger than oneself, can happen even when life's circumstances are difficult. This experience of the mystery of God's presence, or the imprecise but real sense of being connected to the larger universe, can occur "even in the midst of suffering or pain" (McCall, 2015, p. 201). Indeed, it is possible to imagine a transcendent future, a future where this connection with the universe is even more palpable, in "the ordinary events of life, even the painful and frustrating events of life" (McCall, 2015, p. 201). This is the notion of cosmic consciousness, a kind of deep meditative prayer which transcends religions, in which the person moves above his or her self-centredness and becomes "increasingly identified with life in all its myriad forms" (Basset, 1972, p. 119). The Indian poet Rabindranath Tagore (Tagore, 1966) puts it eloquently:

The vitality that flows in waves, night and day, through every vein of my body, flows out to conquer the universe; pulsates through the world in amazing rhythm and cadence; inspires every pore of the earth's soil with the thrill of a million grass-blades growing; blossoms into flowers and young leaves; sways, 
year after year, in the ceaseless ebb and flow of the undulating world-wide sea of life and death.

That endless vitality, absorbed into my being, exalts me in every limb. In my veins dances today that vast rhythm of aeons. (p. 80)

\title{
Appendix A: Review of the Day
}

\author{
(An Adaptation of St Ignatius Examen of Consciousness) \\ Grant Bullen (2010a)
}

\section{STEP 1: PREPARING}

Settle yourself in a quiet, conducive space. Set aside 20-30 minutes. Light a candle. Have your journal ready if it helps to write. Make sure you are comfortable, warm and undisturbed.

Then in the silence, imagine God looking at you in love. Stay with this for a minute or two if you can.

\section{STEP 2: PRAY FOR LIGHT}

Simply ask God for illumination. "What do you want me to see? Reveal to me what is important and let me see clearly."

\section{STEP 3: REVIEW THE DAY}

Mentally scroll through the events, relationships, encounters of the previous 24 hours. Look for those that stand-out (for any reason). If it helps to write them down, record them in your journal. Dot points are fine as this is an aid to memory and so detail is not required.

St. Ignatius encourages us to do this with a particular emphasis on gratitude, and so we offer simple prayers of thankfulness to God as this feeling flows into our hearts.

\section{STEP 4: NOTE THE FEELINGS}

Our feelings, positive and negative, are clear signals of where the "action" was during the day. Simply pay attention to any and all those feelings as they surface, without censorship.

This step will generally occur simultaneously with step 3. It is important that we note the feelings and not push them away.

\section{STEP 5: CHOOSE AN EVENT AND DISCUSS IT WITH GOD}

Our feelings will generally reveal which particular event to focus on. The strongest feeling response is normally the one to choose.

Explore the event and the feelings as deeply as you are able. Allow this exploration to be a conversation/dialogue with God. You might ask: 
- Why did I feel so strongly about this?

- Is this a repetitive happening in my life?

- Was I open to your movement in this?

- Did I respond faithfully....healthily....in freedom?

So it is not an exercise in self-analysis, so much as a dialogue with God. If it helps, use your journal for this conversation.

\section{STEP 6: NEW AWARENESS}

If discernment or new awareness comes in this conversation, note it. See if it can be expressed as an invitation-that is, "God invites me to see this differently"...or whatever.

If the awareness is predominantly one of failure, ask for God's forgiveness straight away. Don't carry this away with you, for God is present and ready to forgive. Whatever is revealed to us comes as a gift for our life and freedom, not our condemnation.

\section{STEP 7 LOOK TO THE DAY AHEAD}

We look 'back' in order to look 'forward' and 'outward'. Briefly consider the day ahead-the tasks, meetings, relationships, challenges. Note any feelings attached and immediately offer them to God and spontaneously ask for whatever grace, insight, strength you may need.

And particularly see if the 'new awareness' from yesterday has any application to the coming day.

\section{STEP 8 END IN PRAYER}

Return to the original vision....imagine God looking at you in love. Offer a simple prayer of gratitude. The traditional practice of the Examen ends by saying the Lord's Prayer.

\section{Appendix B: LECTIO DIVINA—"a Way of Reading Scripture Prayerfully"}

Grant Bullen (2010b)

\section{Preparing}

Settle yourself in a quiet, conducive space. Set aside 20-30 minutes. Light a candle. Have your journal ready if it helps to write. Make sure you are comfortable, warm and undisturbed. Then in the silence, imagine God looking at you in love. Stay with this for a minute or two if you can. 
Step 1: "Lectio"

Step 2: "Meditatio"

Step 3: "Meditatio"

Step 4: "Meditatio"

Step 5:

"Oratio"
Read the passage slowly to yourself ... several times. (Some people find that it helps to read it aloud.) As you read, notice the words or phrase that catch your attention

Reflect on the words that catch your attention. Ask God 'why' these particular words speak to you. Where do they connect with your life today? (Don't be in a rush. If the text is a story it might help to imagine yourself as a character ... or simply imagine yourself in the crowd that day ... listening ... watching)

Ask yourself, "What new and different light is this text shedding on my life today?" (We ask what is 'new' and 'different' in order to hear God's Word to us ... rather than drift back into our own thoughts, assumptions and prejudices)

Take your time-there is no rush. If you feel your mind drifting off into 'habitual head-talk', return to the text and ask the question again

Ask yourself, "From what I have heard/seen in this prayerful reading, what does God want me to do or be this day/this week? How does God invite me to change?"

Compose this insight into a simple, one sentence prayer. ("Dear God, may I ... this day/week")

Pray this prayer. Sit quietly, repeating this prayer whenever you feel your mind moving off elsewhere

Step 6: "Contemplatio" Sit in the silence for a while. Whenever distraction comes, return gently to your prayer. The focus is now simply being in God's presence-not expecting or desiring anything to happen, but simply to sit in God's light

\section{End in Prayer}

Return to the original vision....imagine God looking at you in love. Offer a simple prayer of gratitude.

(Note: We all too often read Scripture for information, or sometimes even to extract "right doctrine". But in this method we simply listen, with no other intent than hearing God speak. This is prayer!)

\section{References}

Abbaye Saint-Pierre Solesmes. (2019). Prayer, work and study. Retrieved from https://www.solesmes.com/prayer-work-and-study. 
Australian Bureau of Statistics. (2016). Type of religion. Retrieved from https:// www.abs.gov.au/ausstats/abs@.nsf/Lookup/by\%20Subject/2071.0 2016 Main\% 20Features - Religion\%20Data\%20Summary 70 .

Basset, B. (1972). Let's start praying again: Field work in meditation. London: Sheed \& Ward.

Brooke-Smith, S. (2014, September). Engaging students in Jesus' character strengths. Talk presented at the 2014 Flourishing in Faith conference, Adelaide, SA, Australia.

Bullen, G. (2010a). Review of the day: An adaptation of St Ignatius' "examen of consciousness". Adelaide, SA, Australia: The Julian Centre.

Bullen, G. (2010b). LECTIO DIVINA: A way of reading scripture prayerfully. Adelaide, SA, Australia: The Julian Centre.

Carter, P. (2010). Introduction to review of the day: An adaptation of St Ignatius' "examen of consciousness". Adelaide, SA, Australia: The Julian Centre.

Charry, E. (2017a). Positive psychology and Christian theology: An exchange of gifts. In G. Ambler, M. Anstey, T. McCall, \& M. White (Eds.), Flourishing in faith: Theology encountering positive psychology (pp. 3-18). Eugene, OR: Cascade Books.

Charry, E. (2017b). Theology and psychology in conversation. In M. White, G. Slemp, \& S. Murray (Eds.), Future directions in well-Being: Education organization and policy (pp. 35-38). Heidelberg/New York/London: Springer Press/Dordrecht.

Collaborative for Academic, Social, and Emotional Learning (CASEL). (2018). Retrieved from https://casel.org/.

De Mello, A. (1990). Awareness: The perils and opportunities of reality. New York, USA: Doubleday/Image Books.

Ellis, A. (1957). Rational psychotherapy and individual psychology. Journal of Individual Psychology, 13, 38-44.

Gillham, J., Reivich, K., Freres, D., Chaplin, T., Shatté, A., Samuels, B., ... Seligman, M. (2007). School-based prevention of depressive symptoms: A randomized controlled study of the effectiveness and specificity of the penn resiliency program. Journal of Consulting and Clinical Psychology, 75(1), 9-19.

Harris, T. (2017). Shalom, gospel and the mission of god. In G. Ambler, M. Anstey, T. McCall, \& M. White (Eds.), Flourishing in faith: Theology encountering positive psychology (pp. 65-80). Eugene, OR: Cascade Books.

Hendry, J. (2015). The way forward: Stand up do not stand by (Unpublished essay). Hendry, J. (2019a). Forgiveness and care (Unpublished staff presentation). Adelaide, SA, Australia: St Peter's College.

Hendy, J. (2019b). The way forward. Retrieved from https://www.ggs.vic.edu.au/ins titute/blog/blog-posts/giving-and-relationships.

Kabat-Zinn, J. (1994). Wherever you go, there you are: Mindfulness meditation in everyday life. New York, NY, USA: Hyperion. 
Kempster, H., \& Yaden, D. (2015). Mystics anonymous: An introduction. In D. Yaden, T. McCall, \& J. Ellens (Eds.), Being called: Scientific, secular and sacred perspectives (pp. 283-290). Santa Barbara, CA: Praeger.

Lama, D., Tutu, D., \& Abrams, D. (2016). The book of joy. London: Hutchinson.

Lyubomirsky, S. (2007). The how of happiness: A new approach to getting the life you want. London: Penguin Press.

McCall, T. (2015). Hope and eternity: God as transcendent presence in the ordinary. In D. Yaden, T. McCall, \& J. Ellens (Eds.), Being called: Scientific, secular and sacred perspectives (pp. 193-202). Santa Barbara, CA: Praeger.

McCall, T. (2017a). Drawn into the inner life of the trinity: A dialogue between theology and positive psychology. In G. Ambler, M. Anstey, T. McCall, \& M. White (Eds.), Flourishing in faith: Theology encountering positive psychology (pp. 99-110). Eugene, OR: Cascade Books.

McCall, T. (2017b). Positive psychology, a new interpretative lens for scripture. In M. White, G. Slemp, \& S. Murray (Eds.), Future directions in well-being: Education organization and policy (pp. 35-38). Heidelberg/New York/London: Springer Press/Dordrecht.

McCall, T., Waters, L., \& White, M. (2012). Finding similarities and points of connection between positive psychology and Christianity. Dialogue Australasia, $27,17-21$.

McCall, T., Waters, L., \& White, M. (2015). A comparison between theological Christian approaches to wisdom and Peterson and Seligman's classification of character strengths and virtues. In M. White \& S. Murray (Eds.), Evidence-based approaches to positive education: Implementing a strategic framework for well-being in schools (pp. 27-41). Heidelberg/New York/London: Springer Press/Dordrecht.

New Revised Standard Version Bible (NRSV). (1989). National Council of the Churches of Christ in the United States of America.

Peterson, C., \& Seligman, M. (2004). Character strengths and virtues: A handbook and classification. New York: American Psychological Association, Oxford University Press.

Puhl, L. (1951). The Spiritual Exercises of St Ignatius: A New Translation based on studies in the language of the autograph. Westminster, MD: The Newman Press.

Reivich, K., Seligman, M., Gillham, J., Linkins, M., Peterson, C., Schwartz, B., ... Duckworth, A. (2007). Positive psychology program for high school students: Student notebook. Philadelphia, PA: Positive Psychology for Youth Project.

Tagore, R. (1966). One hundred and one poems. Bombay: Asia Publishing House.

Teilhard de Chardin, P. (1965). Hymn of the universe. New York: Harper \& Row. Retrieved from https://www.religion-online.org/book-chapter/chapter-4pensees/.

Teresa of Avila. (1577). The way of perfection. Retrieved from https://www.ourlad yswarriors.org/saints/wayperf2.htm.

Tutu, D. (2007). Believe: The words and inspiration of Desmond Tutu. Colorado: Blue Mountain Arts. 
Williams, R. (2014). Being Christian: Baptism, Bible, Eucharist, Prayer. London: SPCK.

Williams, R. (2016). Being disciples: Essentials of Christian life. London: SPCK.

Open Access This chapter is licensed under the terms of the Creative Commons Attribution 4.0 International License (http://creativecommons.org/licenses/by/4.0/), which permits use, sharing, adaptation, distribution and reproduction in any medium or format, as long as you give appropriate credit to the original author(s) and the source, provide a link to the Creative Commons license and indicate if changes were made.

The images or other third party material in this chapter are included in the chapter's Creative Commons license, unless indicated otherwise in a credit line to the material. If material is not included in the chapter's Creative Commons license and your intended use is not permitted by statutory regulation or exceeds the permitted use, you will need to obtain permission directly from the copyright holder. 